\title{
Trace fossils from Talchir carbonate concretions, Giridih basin, Jharkhand
}

\author{
S S Das* and Mahesh Kumar Tripathi \\ Department of Earth and Planetary Sciences, Nehru Science Centre, University of Allahabad, \\ Allahabad 211 002, India. \\ *e-mail: siddharthasankar_das@yahoo.co.in
}

\begin{abstract}
The carbonate concretions occurring at the bottom of Talchir fissile shale facies preserved signatures of various trace fossils along with a cast of doubtful organisms and cyanobacterial mat structures. The host shale deposited under glacial melt water fed lacustrine condition. The concretions, formed in poorly oxygenated conditions, are either of syndepositional origin and/or deposited a little below the sediment water interface and were later exhumed to the depositional surface due to erosion of soft mud overlying them.

The trace fossils are both megascopic and microscopic in nature. The megascopic trace fossils are identified on the basis of their morphology as Monocraterion and Rhizocorallium. Some of the megascopic structures described remain problematic at present. The microscopic trace fossils are formed due to the activity of marine meiofauna (possibly by nematodes), which, although produced morphologically show similar traces of known larger ichnogeneras but much smaller than them. The discovery of these trace fossils apparently indicate the influx of saline water into a lacustrine domain during the Talchir sedimentation at Giridih basin. Moreover, presence of the above two megascopic trace fossils in the marine lacustrine carbonate concretions may lead researchers to consider their much wider environmental significance than hitherto believed.
\end{abstract}

\section{Introduction}

The Talchir Group that marks the beginning of Gondwana sedimentation in India is traditionally considered to be of glacial and fluviolacustrine origin (Blanford et al 1856; Rao 1957; Niyogi 1961; Ghosh and Mitra 1975; Sen 1991; Sen and Banerjee 1991; and others), except for a few well-established fossiliferous sequences reported from Umaria (Reed 1928) and Manendragarh in Madhya Pradesh (Ghosh 1954) and Daltonganj in Jharkhand (Dutta 1965). But this concept is under the scanner after the documentation of various signatures of marine environment from several Gondwana basins of India. Fossil polyplacophora (Sengupta et al 1999) and foraminifers (Pal et al 1994) from Talchir sediments, West Bokaro basin; marine pelecypods from Ranigunj basin (Chandra 1994); marine bivalves and brachiopods from the Talchir formation of Son-Mahanadi basin (Casshyap and Arora 1994); marine coccoliths from the Talchir formation, Ramgarh coal field (Chaudhuri and Mandal 1989); trace fossils from the Talchir formation of Raniganj and Deogarh coal fields (Guha et al 1994); and marine algal stromatolites and colonial cyanophytes from the Talchir formation, Talchir basin, Orissa (De 1999) are some of the important findings. Mohanty and Das (1997) reported microbial mat from Talchir basin, Orissa and inferred periodic influx of saline water into the lacustrine domain based on the stable isotope analysis. The sedimentary structures and trace fossils preserved in the Talchir formation of Sahajuri basin indicates its deposition under glaciomarine deltaic environment (Bhattacharya et al 2004; Chakraborty and Bhattacharya 2005). Chakraborty (1993) indicated

Keywords. Trace fossils; Talchir Group; concretions; Giridih basin; environment. 


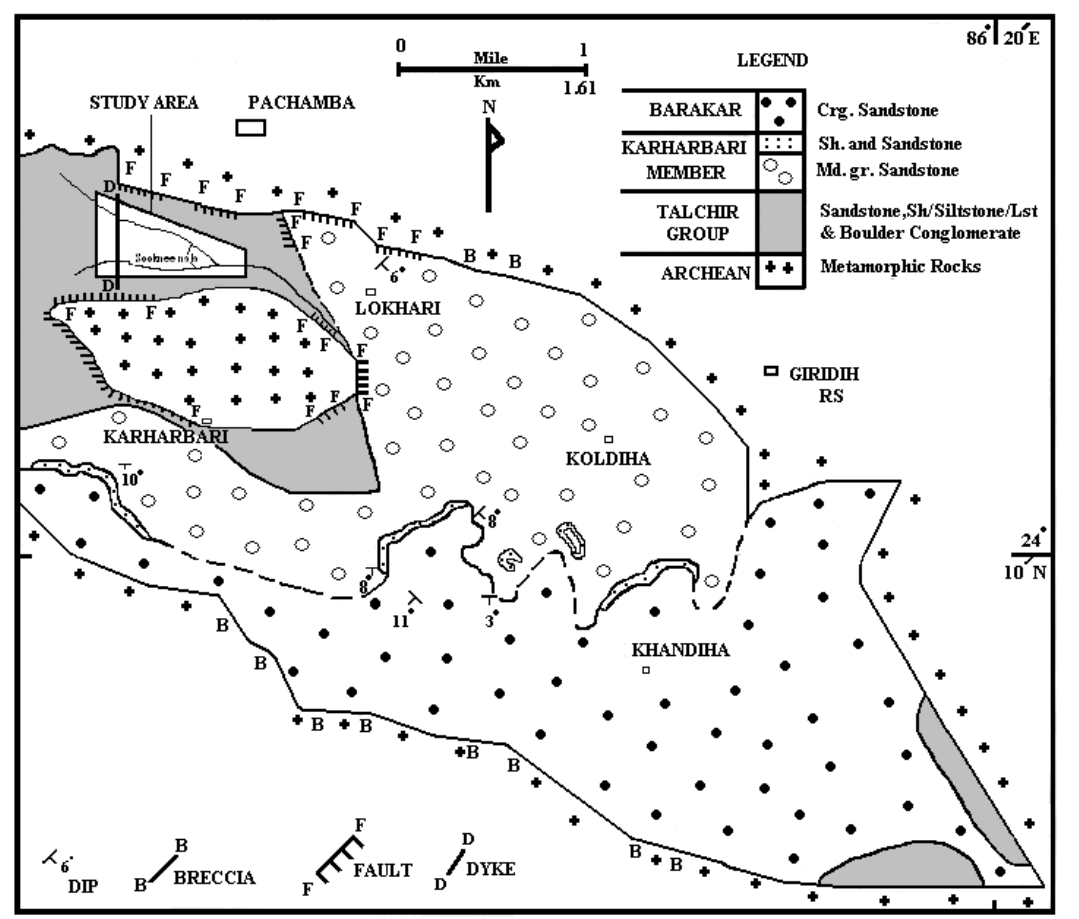

Figure 1. Geological map of Giridih basin (redrawn after Das 1986; Sengupta et al 1988).

marine influence during the deposition of the Talchir group of sediments, Giridih basin on the basis of trace fossils preserved in sandstone.

Concretions and nodules are considered very important because they often provide 'frozen records' of the condition of the sediment at the time of deposition and consolidation processes (Raisewell 1971; Selles-Martinez 1996). Concretions are also given lot of importance because they may often preserve fossils and other biogenic structures. The concretions/nodules found in the Talchir sediment of different Indian Gondwana basins, were predominantly made up of calcareous material (Ghosh et al 2002; Das and Goyal 2007). Based on the trace element and isotopic studies Ghosh et al (2002) suggested fresh water lacustrine depositional environmental condition for the concretions of West Bokaro, Ramgarh (Damodar valley basin), and Talchir (Mahanadi valley basin). The carbonate concretions of various shapes and sizes are found in the Talchir Group sediment, Giridih basin (Damodar valley), Jharkhand. Das and Goyal (2007) studied these concretions for their various crack morphologies. These carbonate concretions have preserved various megascopic trace fossils, doubtful impressions of body fossils, and various signatures of microscopic trace fossils. The objectives of this paper are to describe the above findings and correlate them to a possible environmental set up during the Talchir group sedimentation at Giridih basin.

\section{Geological setting}

The Giridih Gondwana basin, a small WNWESE trending basin in eastern India includes Permocarboniferous sediments belonging to the Talchir group, the Karharbari and Barakar members (Sengupta et al 1988). The presence of a large inlier of Precambrian rocks within the Gondwana sediments is an interesting feature. The inlier is bounded by normal faults on all sides. The Talchir group sediments are predominantly present in the western part of the basin (figure 1). The Talchir group directly overlies precambrian gneissic rocks and in turn are overlain by Karharbari member. The boundary between the Talchir group and the Karharbari member is gradational to the south but a N-S trending fault separates them towards the east. The northern boundary of Talchir group against Precambrian rocks is marked by prominent faulting while the western boundary is an erosional unconformity.

The Talchir group sediments which are mainly exposed in and around the Sooknee Nala (western part) comprises basal boulder conglomerate facies succeeded by khaki-green fissile shale facies, and an upper sandstone facies (table 1). The carbonate concretions, occurring at the bottom part of fissile shale facies, are well exposed at the bed in the north-western part of Sooknee Nala (plate 1A). For detail geologic setting please see Sen (1991). The glacial melt water-fed lacustrine and turbidity 
Table 1. Lithofacies variations at the study area.

\begin{tabular}{|c|c|c|}
\hline Lithofacies & Description & Trace fossils \\
\hline C. Sandstone & $\begin{array}{l}\text { Massive, matrix supported conglomerate } \\
\text { with angular clasts. It laterally as well } \\
\text { as vertically changes to fine grained, yel- } \\
\text { lowish, feldspathic sandstone with spo- } \\
\text { radic pebbles. Sandstone shows parallel } \\
\text { lamination, cross-lamination, and con- } \\
\text { volute lamination. }\end{array}$ & Not reported. \\
\hline B. Shale & $\begin{array}{l}\text { Khaki-green fissile shale with dropstones. } \\
\text { The lower part is massive greyish black } \\
\text { diamictite with negligible clast con- } \\
\text { tent. The diamictite passes upward into } \\
\text { bluish-grey laminated calcareous silt- } \\
\text { stone which is often sandy. The carbon- } \\
\text { ate concretions occurring at the bottom } \\
\text { of fissile shale and above siltstone. Some } \\
\text { of the concretions show dropstones. The } \\
\text { shale facies also contains few stringers } \\
\text { of fine grained laminated sandstone and } \\
\text { siltstone. The sandstone shows ripple- } \\
\text { drift lamination. Striations and chatter } \\
\text { marks preserved on the siltstone. The } \\
\text { upper part of the facies is weakly strati- } \\
\text { fied and interlayered with rhythmites. }\end{array}$ & $\begin{array}{l}\text { Burrows in the sandstone: Zoophycos, } \\
\text { Skolithos, Planolite and Teichichnus } \\
\text { (Chakraborty 1993). Trace fossils } \\
\text { in the carbonate concretions (this } \\
\text { paper). }\end{array}$ \\
\hline $\begin{array}{l}\text { A. Boulder conglomer- } \\
\text { ate (Diamictite) }\end{array}$ & $\begin{array}{l}\text { Massive, poorly sorted conglomerate with } \\
\text { clayey and sandy matrix. The clasts are } \\
\text { dominantly cobble size with occasional } \\
\text { boulders. Boulders are often faceted. } \\
\text { The conglomerate passes upward in to } \\
\text { a bluish-grey fine grained laminated cal- } \\
\text { careous siltstone. The siltstone in places } \\
\text { sandy and cross-laminated. }\end{array}$ & $\begin{array}{l}\text { Horizontal and vertical burrows in silt- } \\
\text { stone (Sen 1991). Burrows are not } \\
\text { classified. }\end{array}$ \\
\hline
\end{tabular}

current deposition is suggested for the shale lithofacies (Sen 1991).

\section{Carbonate concretions}

The concretions occur as laminated bodies of varying shapes and sizes. The laminations of the shale could be traced in continuity to the concretions. The concretions are grey-black coloured, dense and compact with diameters varying between $4 \mathrm{~cm}$ and $50 \mathrm{~cm}$. On the basis of their morphology Das and Goyal (2007) classified them into three categories: cabbages like growth, domed up growth structure with laminae are warped towards periphery, and discoid bodies with concentric structure at plan view. The vertical axis in all the above varieties is smaller than horizontal axis. Some of the concretions show the presence of dropstones, both, on the surface as well as within them (plate 1B). The vertical section of discoidal concretions show two types of layering: (i) laminae are tapered to the major axis of the concretion, and (ii) parallel laminae without any deformation. In both the cases, they show repeated parallel layers of dark black coloured, fine grained, crinkled layer and relatively lighter grey coloured, fine grained layer (plate 1C). These layers have developed due to seasonally changing water depths corresponding to fluctuations in light intensities which triggered the stacked buildup of sets of dark and light laminae. The dark horizontal layers are rich in filamentous cyanobacterial mat formed during the winter, whereas the light layers rich in sediment formed during the summer (Gerdes 2007). The deformed laminae are of syncompactional origin with the host shale. At small depths with continuous deposition sediment compacts rapidly and growing concretion develops deformed laminae (Raisewell 1971). The concretions are predominantly made up of calcite and quartz with little feldspar, pyrite and clay minerals (illite and chlorite). The insoluble residue content of these bodies varies between $30 \%$ and $38 \%$. The organic matter content varies between $0.5 \%$ and $1.5 \%$ (Goyal 2005). Das and Goyal (2007) suggested that some of the concretions were clearly of syndepositional origin, whereas, some were formed a little below the sediment water interface, later exhumed to the depositional surface by erosion of the soft mud overlying them, 

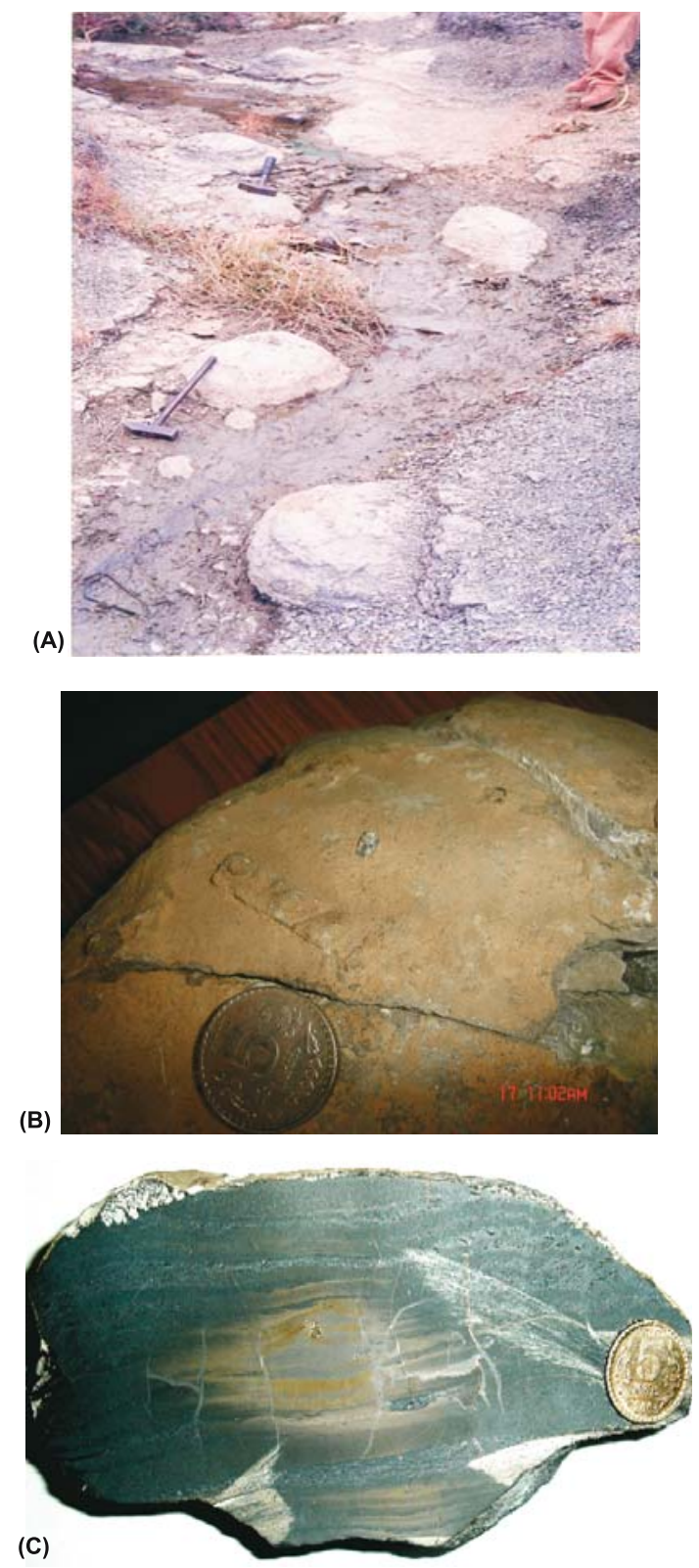

Plate 1. The carbonate concretions: (A) The concretions occurring at the bottom of fissile shale facies in the Sooknee Nala bed. Hammer length: $31 \mathrm{~cm}$. (B) The various sized dropstones attached on the concretion. Coin diameter $23 \mathrm{~mm}$. (C) The vertical section of a concretion showing light and dark (filamentuous mat) laminae. Yellow colour of laminae indicates weathering products of pyrite. Coin diameter $23 \mathrm{~mm}$.

which allowed organisms to bore into them. The grey-black colour, presence of pyrite and organic matter in these concretions indicate that these were formed under poorly oxygenated conditions.

\section{Methodology}

The organo-sedimentary structures are observed after careful study of outcrops, either by breaking concretions, removing, or by cutting concretions parallel/vertical to the laminations. Some of the above structures are preserved as casts in calcareous concretions and others are traced by their physical appearances, both, in hand specimens and in thin sections. All the organo-sedimentary structures are photographed, majority of them sampled and kept with the first author at the Department of Earth and Planetary Sciences, University of Allahabad, Allahabad, India. The above structures which were studied in hand specimen and in the field are described as megascopic structures, whereas, the structures studied in thin sections are described as microscopic ones (table 2). The trace fossils are identified and named after Benton and Harper (1997) and Lindholm (1987). The microscopic trace fossil signatures are morphologically compared to the traces of large known icnogeneras. The depositional environmental conditions for trace fossils are suggested after Seilacher $(1967,1978)$ and Frey (1975).

\section{Discussion}

The deposition of these concretions occurred under poorly oxygenated lacustrine conditions. Seasonal cooling and warming helped in the development of biovarvite during the formation of concretions. These kinds of laminations are also in favour of marine lacustrine conditions. The poorly oxygenated condition is not very suitable for active growth of benthos (Sengupta 2007). But table 2 shows that these concretions have preserved a good number of trace fossils. Trace fossils, reflect behaviour and morphology of the metazoans that formed them and exhibit great diversity and complexity of morphology (Gong and Si 2002; others). Earlier several workers reported trace fossils from the restricted lagoon mud and dysaerobic depositional conditions (Jamieson 1969; Arya and Rao 1979; Wignall 1991; Das and Rao 1992). Pike et al (2001) reported abundant meiofauna (nematode burrows) in the recent severely dysoxic, laminated sediments from the Santa Barbara basin, California margin, and also microcavities and microtunnels in laminated deglacial sediments from Palmer Deep, west Antarctic Peninsula. All of them indicated that although environment was fetid, it supported a benthonic community of predominantly soft bodied mud ingesting organisms. The Monocraterion of Skolithos ichnofacies is widespread in littoral sandy to rocky shores with high energy conditions (Seilacher 1967; Crimes 1975; Frey 1975; Rhoads 1975). The trace fossil Rhizocorallium of Cruziana ichnofacies also indicates a shallow marine condition. The environmental conditions for these trace fossils do not suit the suggested glacio-lacustrine 
Table 2. Description of the various trace fossils and doubtful organo-sedimentary structures.

\begin{tabular}{lll}
\hline Description of trace fossil morphology & Ichnotaxa & Remarks \\
\hline
\end{tabular}

\section{A. Megascopic trace fossils:}

Opening with concentric rings on plan view, diameter varies between 0.5 and $2 \mathrm{~cm}$; vertical to subvertical tubular structures; discordant to the laminations; unbranched; funnel top; either retrussive meniscus filling type or protrussive spreites; length varies between 3 and $12 \mathrm{~cm}$; chambers filled with either limonitic or pyritic material. (Plate 2A, B and C)

U-shaped burrow with spreite, subhorizontal; full relief; burrow filled with calcareous mud and clayey material; burrow dim. $1.0 \mathrm{~cm}$, length $2.5 \mathrm{~cm}$ and distance between the limbs of $\mathrm{U}-1.3 \mathrm{~cm}$. (Plate 2D)

Concave cast of some material at the base of one of the concretions; prominent boundary of cast with umbo like feature; growth structure of concretion can be seen around the cast. The maximum length $6.9 \mathrm{~cm}$ and width $5 \mathrm{~cm}$. (Plate 2E)

Slightly elliptical cast of a material inside of a broken concretion; central ridge; two lobes at the apex are extended to the bottom; length $2.3 \mathrm{~cm}$ and width $1.4 \mathrm{~cm}$ (Plate 2F)

\section{B. Microscopic trace fossils:}

Vertical to slightly inclined, straight, discordant to the lamination; unbranched; uniform width $(0.2-0.3 \mathrm{~mm})$ along length; slightly tapering lower end, weak lining at the wall; internal cavity filled with non-laminated almost homogeneous lime mud. Length $2-2.5 \mathrm{~mm}$. (Plate 3A)

Tubular, funnel top; concentric opening (plan) (diameter $0.25-0.45 \mathrm{~mm}$ ); vertical to subvertical, straight, discordant to the lamination; unbranched; thin lining, meniscus type spreite; tapering bottom; filled with alternately dark lime mud/pyritic material and lighter coloured lime mud, length: $1-2 \mathrm{~mm}$. (Plate $3 \mathrm{~B}, \mathrm{C}$ and $\mathrm{D}$ )

Tubular structures, vertical to subvertical, discordant to the lamination; slightly swollen central part of the tube; meniscus filling type spreite; filled with alternate light and dark coloured lime mud; tapered top and bottom; outer surface of tubes marked by numerous striae, length: $0.45-0.5 \mathrm{~mm}$. (Plate 3E)

Vertical to subvertical, discordant to the lamination; unbranched; tapered top and bottom; non-uniform thickness; length and width widely vary; laminae slightly bent into the burrow chamber; cavity filled with either homogeneous lime mud or alternating lime mud and sparry calcite with few fragments of laminae. (Plate $4 \mathrm{~A}$ and $\mathrm{B}$ )

Long tubular, horizontal branching; oblique to the laminations; uniform width $(\sim 0.1 \mathrm{~mm})$; filled with homogeneous lime mud. (Plate 4C)
Monocraterion of Skolithos ichnofacies

Rhizocorallium of Cruziana ichnofacies

Not known

Not known

Trace of meiofauna Trichichnus(?) isp.

Trace of meiofauna

Meiofaunal trace

Meiofaunal trace

Meiofaunal trace
Monocraterion represents dwelling burrows inhabitated by gregarious, suspension feeding worm like animal; shallow marine (littoral) environment.

Burrows of deposit-feeding animals or dwelling burrows of filter feeders. Littoral to neritic environment.

The cast is likely to be of unknown bivalvia(?).

The cast is of soft bodied organism at present remained problematical.

Morphologically very similar to Skolithos but much smaller than those. Trichichnus reported from shelf area (Frey 1975).

Morphologically similar to Monocraterion but of microscopic scale.

Morphologically very similar to Rhizocorallium of Glossifungites ichnofacies.

Burrow structure likely to be due to bivalve boring, commonly found in shoreline rocks or in lithified limestone hard grounds on the seabed.

Morphologically similar to Thallassinoid of Glossifungites ichnofacies. 
Table 2. (Continued).

\begin{tabular}{|c|c|c|}
\hline Description of trace fossil morphology & Ichnotaxa & Remarks \\
\hline $\begin{array}{l}\text { Small tubular; branched; straight to slightly } \\
\text { curved; thickness variable }(<0.1-2 \mathrm{~mm}) ; \text { filled } \\
\text { with lighter coloured lime mud. (Plate } 4 \mathrm{D})\end{array}$ & $\begin{array}{l}\text { Chondrites (?) of } \\
\text { Cruziana } \\
\text { ichnofacies }\end{array}$ & $\begin{array}{l}\text { Feeding burrow of sediment eating } \\
\text { wormlike organism, marine lit- } \\
\text { toral to abyssal depth. }\end{array}$ \\
\hline $\begin{array}{l}\text { Radiating traces of vaguely defined tubes from } \\
\text { a central point; almost circular in plan (dia- } \\
\text { meter } 1.4 \mathrm{~mm} \text { ); filled with alternately slightly } \\
\text { dark and light coloured lime mud with some silt } \\
\text { to clay sized detrital grains. (Plate } 4 \mathrm{E} \text { ) }\end{array}$ & Trace of meiofauna & $\begin{array}{l}\text { The trace fossil morphologically } \\
\text { similiar to the Zoophycos (spiral) } \\
\text { type. }\end{array}$ \\
\hline $\begin{array}{l}\text { The structures occurring parallel to lamination; } \\
\text { two lobes with a central ridge, lobe width: } \\
0.15-0.2 \mathrm{~mm} \text {, lobes have very fine rib like fea- } \\
\text { tures occurring at an angle to the central ridge; } \\
\text { lobes filled with lime mud and silt-clay sized } \\
\text { detrital grains. (Plate } 5 \mathrm{~A} \text { and } \mathrm{B} \text { ) }\end{array}$ & Meiofaunal trace & $\begin{array}{l}\text { The structures are morphologically } \\
\text { similar to trace fossil Cruziana of } \\
\text { Cruziana cihnofacies. }\end{array}$ \\
\hline $\begin{array}{l}\text { Horizontal tubular structure, curved, almost uni- } \\
\text { form width }(\sim 0.13 \mathrm{~mm}) \text {; unbranched; wall } \\
\text { partly lined with bright coloured lime mud and } \\
\text { detrital grains; filled with homogeneous lime } \\
\text { mud; length } 0.4 \mathrm{~mm} \text {; pyrite patches present. } \\
\text { (Plate } 5 \mathrm{C})\end{array}$ & Meiofaunal trace & $\begin{array}{l}\text { The trace morphologically com- } \\
\text { parable to Teichichnus tube of } \\
\text { Cruziana ichnofacies. }\end{array}$ \\
\hline $\begin{array}{l}\text { Wavy, bundle of thin tubes; discontinuous; paral- } \\
\text { lel to the laminations; made of light coloured } \\
\text { lime mud. (Plate 5D) }\end{array}$ & $\begin{array}{l}\text { Sheath bundle of } \\
\text { Microcoleus } \\
\text { chthonoplastes }\end{array}$ & $\begin{array}{l}\text { A species capable of sediment bind- } \\
\text { ing (Gerdes 2007). }\end{array}$ \\
\hline $\begin{array}{l}\text { Dark coloured, crinkcled, discontinuous; thin } \\
\text { layers; parallel to the laminations; interlayered } \\
\text { with lighter coloured lime mud; often sur- } \\
\text { rounded by spar. (Plate } 5 \mathrm{E} \text { ) }\end{array}$ & Cyanobacterial mats & $\begin{array}{l}\text { Biovarvites showing sequence of fil- } \\
\text { amentuous mat (dark laminae: } \\
\text { winter mat, light laminae: sum- } \\
\text { mer mat). Mats destroyed by } \\
\text { critical point drying. Common in } \\
\text { peritidal lagoons. }\end{array}$ \\
\hline
\end{tabular}

environment of deposition of the host shale, as well as of concretions. But the trace fossils observed here are indeed morphologically similar to the above known ichnogeneras. Chakraborty (1993) also indicated marine influence during the Talchir group sedimentation, Giridih basin on the basis of trace fossils (Zoophycos, Planolite, Skolithos and Teichichnus) observed in the sandstone associated with shale facies. These observations apparently indicate influx of saline water into a lacustrine domain during the sedimentation of Talchir fissile shale lithofacies at Giridih basin.

The crinkled and discontinuous laminae that make up the calcareous laminated concretion have a close resemblance to cyanobacterial mats (Gerdes 2007). These types of algal laminations were described as horizontal stromatolites probably Weedia type (Pettijohn 1975). Similar types of laminae were also reported earlier from the Proterozoic Charmuria limestone of Chattisgarh (Das and Rao 1992), Narji limestone of Kurnool basins (Arya and Rao 1979), Cretaceous algal-deposits of Valencia, Spain (Monty 1981), Proterozoic sediments of South Africa (Bertrand-Sarfati and
Pentecost 1992), and Saltworks, Canary Islands, Spain (Gerdes et al 1991, 2007). Bertrand-Sarfati and Pentecost (1992) described such dark, often discontinuous growth of algae as Tussocky structure and compared them with modern stromatolite builder Rivularia. If algae were actively present during the growth of these concretions then the question that arises is whether the other microscopic organo-sedimentary structures are also due to the activity of algae. Milliman (1974) suggested that endolithic algal colonies can bore their substrates. The diameters of algal borings (Golubic 1969) range from $5-15 \mu \mathrm{m}$, while the diameters of these micro-organo-sedimentary structures are much larger than this size. Thus the algae as agents of these borings are ruled out. Fungi and bacteria may also be ruled out as active borers for the similar reason. These microscopic structures apparently seem to be made by meiofauna (animal ranging in size from approximately $0.1 \mathrm{~mm}$ to $1 \mathrm{~mm}$ that live within the sediment). They have made morphologically similar signatures in sediments to larger known ichnogeneras reported mostly from the sandy horizons, but much smaller than them. 

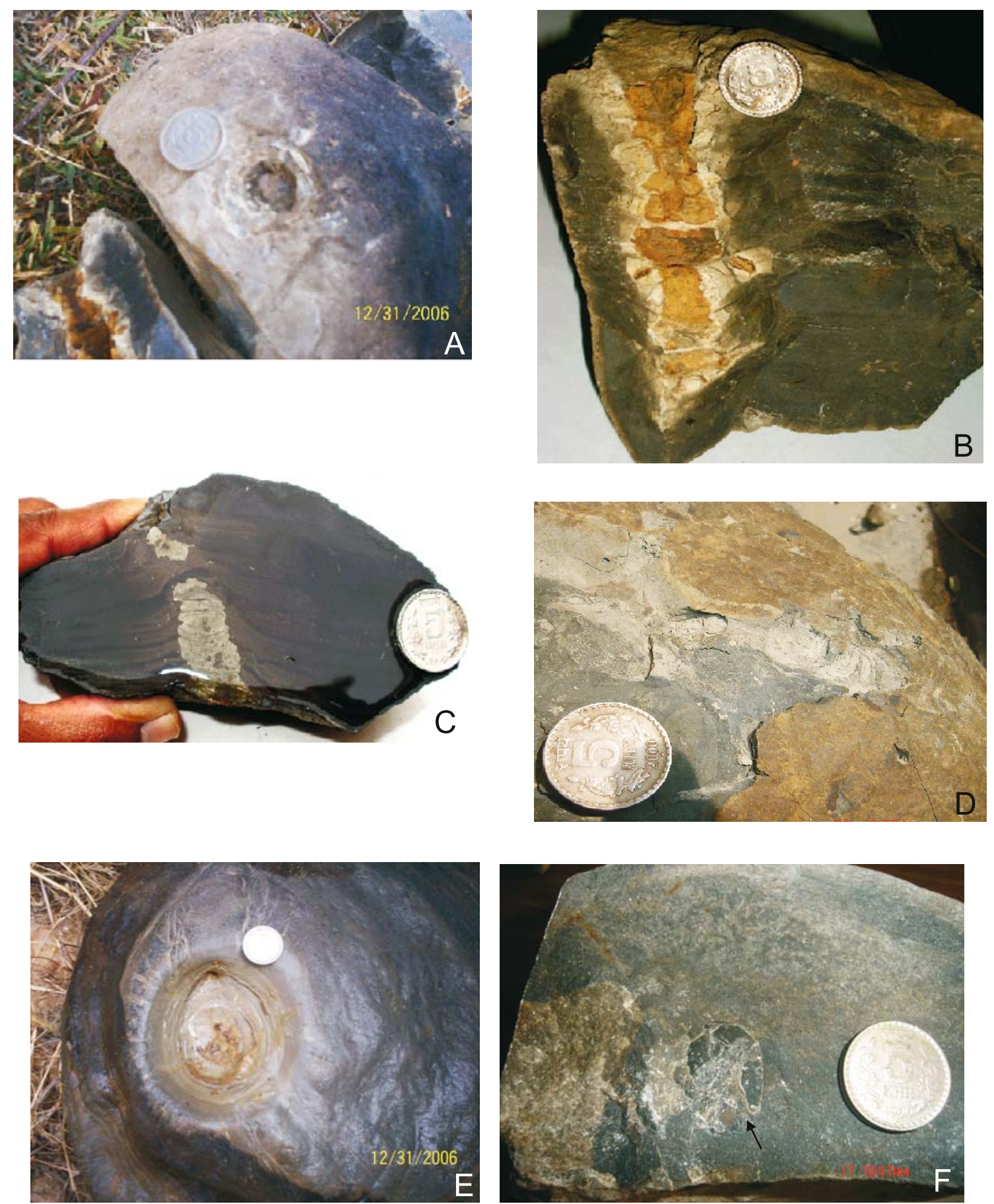

Plate 2. Megascopic trace fossils (coin is used as scale, diameter: $23 \mathrm{~mm}$ ). (A) Monocraterion (plan view): an opening with concentric rims. The mouth of the hole is filled with pyrite. (B) and (C) The vertical section of the concretions showing trace fossil Monocraterion with two different types of spreites. The internal cavity is filled with pyrite/limonitic material. (D) Rhizocorallium: the U-shaped burrow with spreite (plan view). (E) The cast of an unknown bivalvia observed at the base of one of the concretions in the field. (F) The cast of an unknown soft bodied organism observed inside of a broken concretion (shown by an arrow).

The morphological behaviour of these micro-trace fossils are compared to the traces of larger known ichnogeneras because, there is very little information about the effects and implications of meiofaunal burrowing on the geological record (Meadows et al 1994; Pike et al 2001; and others), although origin and economic assessment of meiofauna is a well-developed subject (Boaden 1989; Platt 1989; Funch 2002). However, the meiofauna are by no means a homogeneous ecological group. There is a wide diversity of habitat in which meiofauna live. In general, sediment grain-size is a primary factor 

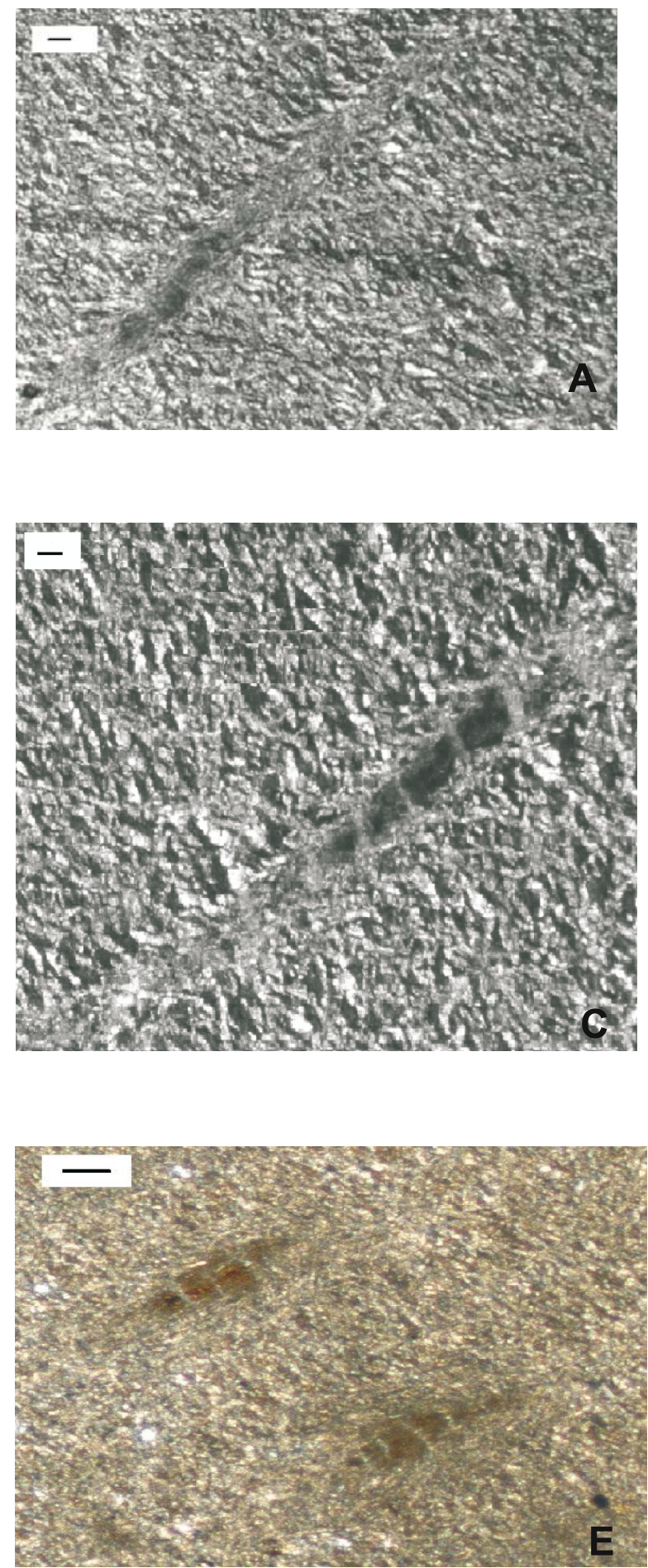
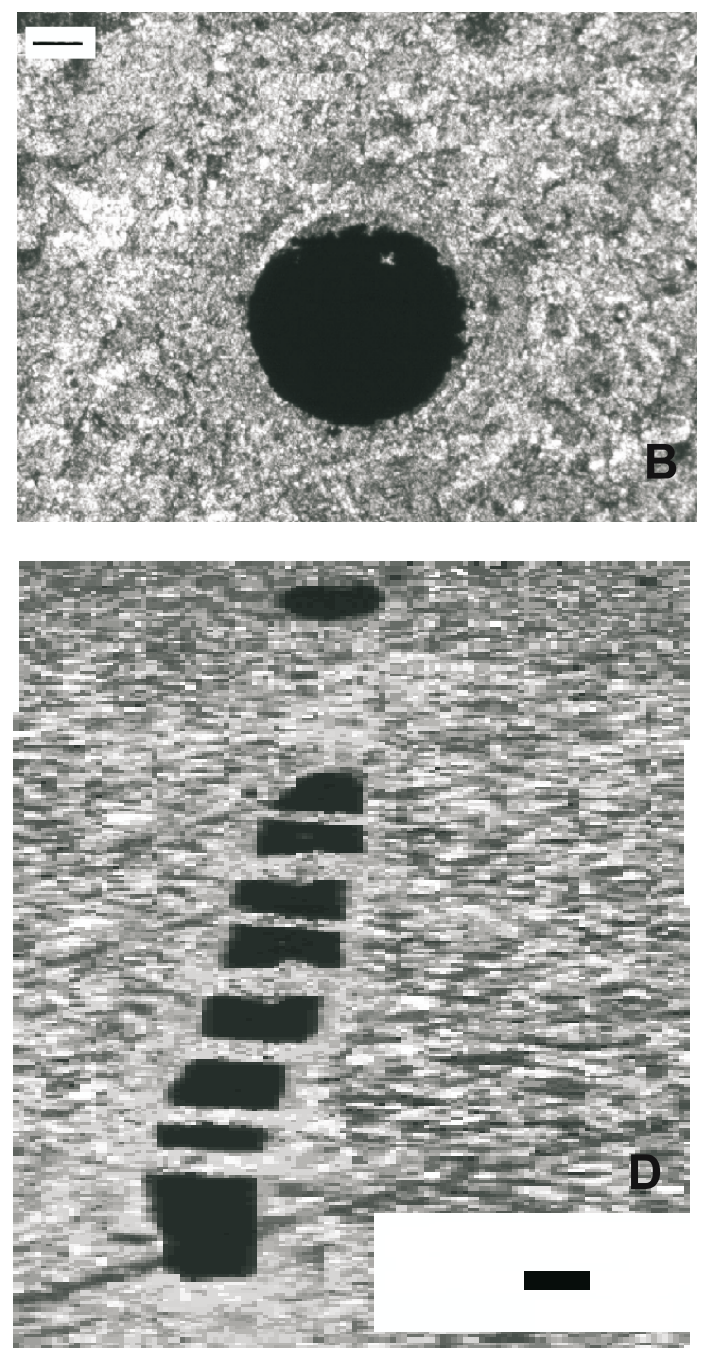

Plate 3. Thin section images of trace fossils. Uncrossed. Thin sections made perpendicular $(\mathbf{A}, \mathbf{C}, \mathbf{D}$, and $\mathbf{E})$, and parallel to the laminations (B). (Scale bar $=100 \mu \mathrm{m}$.) (A) A vertical burrow, without internal laminae. The cavity is filled with lime mud. (B) An opening with concentric rims. The mouth is filled with pyrite. (C) and (D) are sectional views of this trace fossil. (C) and (D) Vertical to subvertical, discordant to the laminations, tubular micro-trace fossils with meniscus type spreite. Funnel top is visible in (C). Cavities filled with alternately dark and light coloured lime mud/pyritic material. (E) Vertical to subvertical, discordant to the lamination, tubular structures with swollen central part. Tapered top and bottom. Meniscus filling type spreite; outer surface marked with numerous striae. Filled with alternately dark and light lime mud. affecting the abundance and species composition of meiofaunal organisms. Nematodes (permanent meiofauna) regularly dominate the meiofauna in sediment. The length of marine nematodes is usually around $1-3 \mathrm{~mm}$. The smallest nematodes are smaller than $0.2 \mathrm{~mm}$. The dimensions of marine nematodes conform to the dimensions of the microtrace fossils found here. The nematodes are usually bound to the substrate. They can live from dry dune sand, to beach sand, down to hadal zone (Riemann 1979). The above observations indicate that these micro-traces are possibly made by nematodes of marine origin. Further, if the observed variation in morphological structures is considered to be due to ichnodiversity, then the environment is likely to have had characteristic marine influence during sedimentation. The preservation of such microscopic traces in these concretions also 

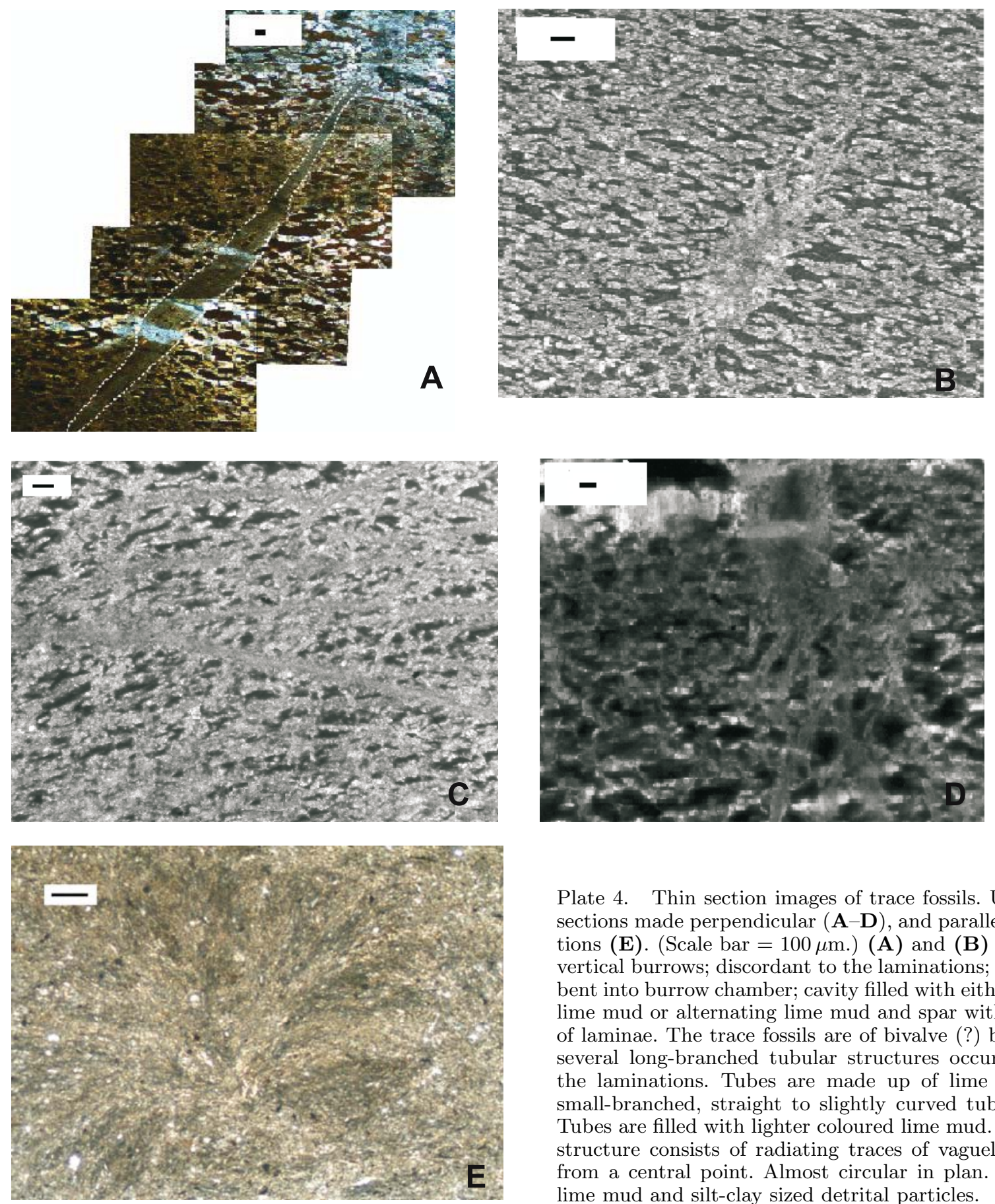

Plate 4. Thin section images of trace fossils. Uncrossed. Thin sections made perpendicular $(\mathbf{A}-\mathbf{D})$, and parallel to the laminations $(\mathbf{E})$. (Scale bar $=100 \mu \mathrm{m}$.) $(\mathbf{A})$ and $(\mathbf{B})$ Vertical to subvertical burrows; discordant to the laminations; laminae slightly bent into burrow chamber; cavity filled with either homogeneous lime mud or alternating lime mud and spar with few fragments of laminae. The trace fossils are of bivalve (?) boring. (C) The several long-branched tubular structures occurring oblique to the laminations. Tubes are made up of lime mud. (D) The small-branched, straight to slightly curved tubular structures. Tubes are filled with lighter coloured lime mud. (E) The microstructure consists of radiating traces of vaguely defined tubes from a central point. Almost circular in plan. It is filled with lime mud and silt-clay sized detrital particles.

indicate that they were formed immediately after the deposition of sediment. The pyritic burrow fillings probably occurred partly due to pyritization of organic matter derived from the burrowing organism and partly due to foreign material (Thomsen and Vorren 1984).

\section{Conclusions}

The carbonate concretions occurring at the bottom of Talchir fissile shale preserved signatures

of various trace fossils along with cast of doubtful organisms and cyanobacterial mats. The host shale deposited under glacial melt water-fed lacustrine condition. The grey-black coloured calcareous concretions are of different morphology. They have formed in poorly oxygenated lacustrine conditions. The concretions are either of syndepositional origin and/or deposited a little below the sediment water interface and later exhumed to the depositional surface due to erosion of soft mud overlying them. 

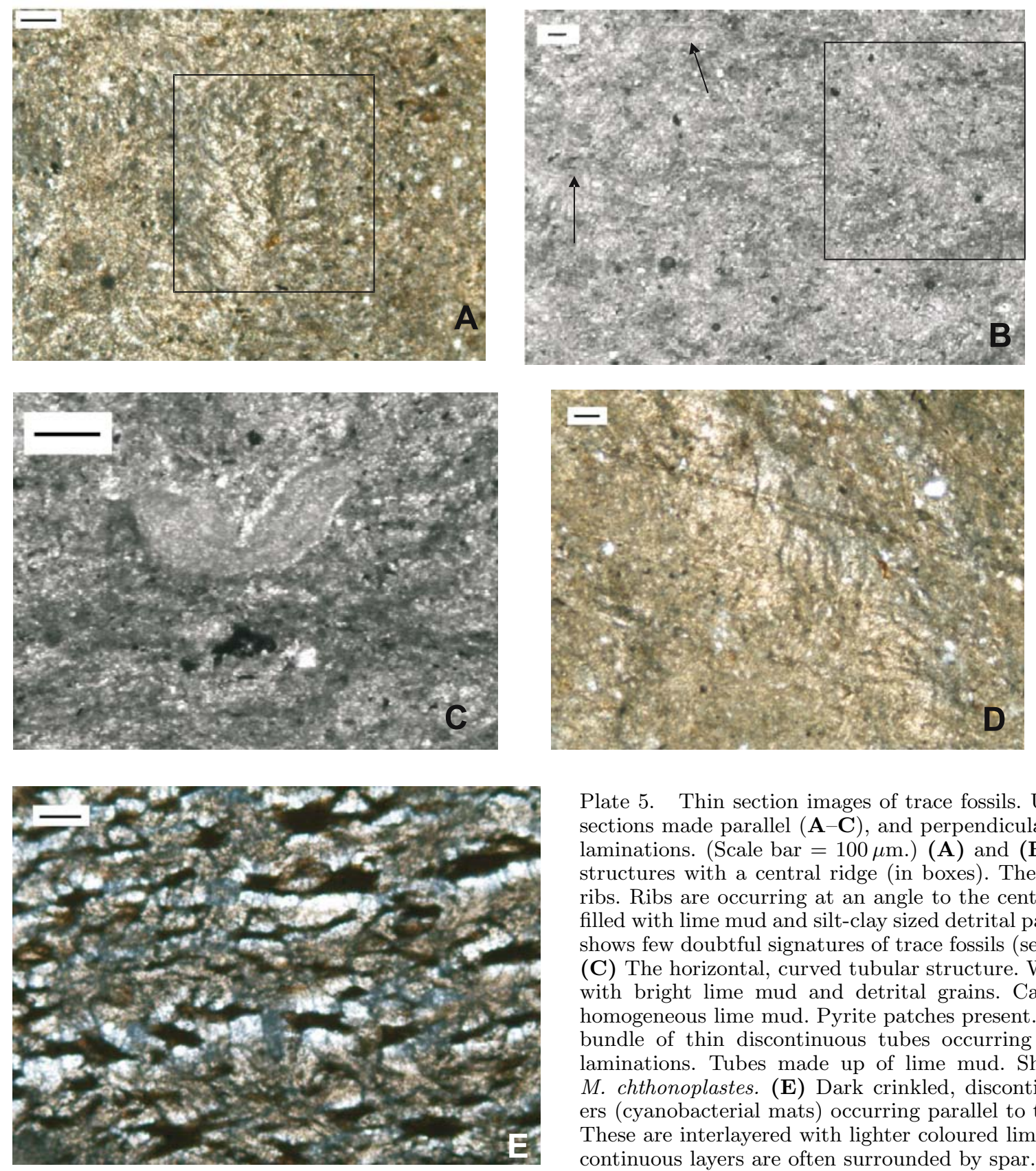

Plate 5. Thin section images of trace fossils. Uncrossed. Thin sections made parallel $(\mathbf{A}-\mathbf{C})$, and perpendicular $(\mathbf{D}-\mathbf{E})$ to the laminations. (Scale bar $=100 \mu \mathrm{m}$.) $(\mathbf{A})$ and (B) The bi-lobed structures with a central ridge (in boxes). The lobes have fine ribs. Ribs are occurring at an angle to the central ridge. Lobes filled with lime mud and silt-clay sized detrital particles. (B) also shows few doubtful signatures of trace fossils (see arrow marks). (C) The horizontal, curved tubular structure. Wall partly lined with bright lime mud and detrital grains. Cavity filled with homogeneous lime mud. Pyrite patches present. (D) The wavy, bundle of thin discontinuous tubes occurring parallel to the laminations. Tubes made up of lime mud. Sheath bundle of M. chthonoplastes. (E) Dark crinkled, discontinuous thin layers (cyanobacterial mats) occurring parallel to the laminations. These are interlayered with lighter coloured lime mud. The discontinuous layers are often surrounded by spar.

The trace fossils are both megascopic and microscopic in nature. The megascopic trace fossils are identified on the basis of their morphology as Monocraterion and Rhizocorallium. The other two megascopic structures described remain problematic at present. The microscopic trace fossils are formed due to the activity of marine meiofauna (possibly by nematodes), which, although produced morphologically show similar traces of known larger ichnogeneras but much smaller than them. The megascopic trace fossils although indicating shallow marine environmental condition, do not conform to the environment of deposition of host shale and concretions. The discovery of these trace fossils apparently indicate influx of saline water into a lacustrine domain during the Talchir sedimentation at Giridih basin. Moreover, the presence of these trace fossils in the marine lacustrine carbonate concretions may lead researchers to consider their much wider environmental significance than hitherto believed.

\section{Acknowledgements}

The authors are thankful to Dr J K Pati, Reader, Department of Earth \& Planetary Sciences, University of Allahabad for allowing us to take digital 
images of trace fossils with the help of a microscope purchased under DST Project. The support provided by Baghedia Dharamsala Society, Pachamba, Giridih during the field work was of great help. Authors are also thankful to two anonymous reviewers for constructive comments, which helped to improve the quality of the paper.

\section{References}

Arya B C and Rao C N 1979 Bioturbation structures from the Middle Proterozoic Narji Formation, Kurnool Group, Andhra Pradesh, India; Sedim. Geol. 22 127-134.

Benton M J and Harper D A T 1997 Basic Paleontology; Longman, $342 \mathrm{p}$.

Bertrand-Sarfati J and Pentecost A 1992 Early Proterozoic biological events (Berlin: Springer) pp 468-477.

Bhattacharya H N, Bhattacharya B, Chakraborty I and Chakraborty A 2004 Sole marks in storm bed in the Permo Carboniferous Talchir Formation, Raniganj Basin, India; Sedim. Geol. 166 209-222.

Blanford W T, Blanford H F and Theobold W Jr. 1856 The geological structure and relations of the Talchir coalfield in the district of Cuttack; Geol. Surv. India Memoir 1 $33-38$.

Boaden P J S 1989 Meiofauna and the origin of the metazoa. Zoolog; J. Linnean Soc. 96 217-227.

Casshyap S M and Arora M 1994 Lithofacies analysis of the Late Paleozoic Talchir Formation in the northern parts of Son-Satpura Gondwana basins, M.P., India: Their implication in reconstruction of paleoenvironment; Ninth Int. Gond. Symp., Abstract, Hyderabad, $54-55$.

Chakraborty A 1993 Marine influence during Talchir deposition, Giridih basin, Bihar; Indian J. Geol. 65 290-292.

Chakraborty A and Bhattacharya H N 2005 Ichnology of a Late Paleozoic (Permo-carboniferous) glaciomarine deltaic environment, Talchir Formation, Saharjuri Basin, India; Ichnos. 12 31-45.

Chandra S K 1994 Marine signatures in the Gondwana of peninsular India and Permian Paleogeography; Ninth Int. Gond. Symp., Abstract, Hyderabad, 61-62.

Chaudhuri S and Mandal K 1989 Eotomariidae gastropods in the Talchir Formation of Ramgarh Coalfield and its paleoenvironmental significance; J. Geol. Soc. India 34 665-668.

Crimes T P 1975 The stratigraphical significance of of trace fossils; In: The study of trace fossils (ed.) R W Frey (New York: Springer) 109-130.

Das S S 1986 Stratigraphic status of the Karharbari rocks, Giridih basin, Bihar; Unpublished M.Sc. Project Report, IIT, Kharagpur, 46 p.

Das S S and Rao C N 1992 Micro-burrows from the Charmuria Formation, Madhya Pradesh, India; Palaios $\mathbf{7}$ 548-552.

Das S S and Goyal S 2007 Crack morphologies in Talchir concretions, Giridih basin, Jharkhand; Natl. Acad. Sci. Lett. 30 295-301.

De C 1999 Algal stromatolites and entrapped colonial marine cynophytes from Talchir limestones, Talchir basin, Orissa: A strong evidence of middle Talchir marine transgression; Indian J. Geol. 71 205-212.

Dutta A B 1965 Fenestella sp. from Talchirs of Daltonganj coal field, Bihar; Quart. J. Geol. Min. Soc. India 37 124-133.
Frey R W 1975 The study of trace fossils (New York: Springer) $562 \mathrm{p}$.

Funch P 2002 Marine meiofauna. Feltkursus I videregaende zoologi pa molslaboratoriet, 1-19.

Gerdes G, Krumbein W E and Reineck H E 1991 Biolaminations - Ecological versus depositional dynamics; In: Cycles and events in stratigraphy (eds) Einsele G, Ricken W and Seilacher A (Berlin: Springer) pp. 592-607.

Gerdes G 2007 Structures left by modern microbial mats in their host sediments; In: Atlas of microbial mat features preserved within the siliclastic rock record (eds) Schieber J, Bose P K, Eriksson P G, Banerjee S, Sarkar S, Altermann $\mathrm{W}$ and Catuneaunu O, Elsevier, pp. 5-38.

Ghosh S K 1954 Discovery of new locality of marine Gondwana Formations; Sci. Culture 19620.

Ghosh P K and Mitra N D 1975 History of Talchir sedimentation in Damodar valley basins; Geol. Surv. India Memoir 105 1-117.

Ghosh P, Bhattacharya S K, Dayal A M, Trivedi J R, Ebihara M, Sarin M M and Chakrabarti A 2002 Trace element and isotopic studies of Permo-Carboniferous carbonate nodules from Talchir sediments of peninsular India: Environmental and provenance implications; Proc. Indian Acad. Sci. (Earth Planet Sci.) 111 87-101.

Golubic S 1969 Distribution, taxonomy and boring patterns of marine endolithic algae; Am. Zool. 9 747-751 (as quoted by Milliman 1974).

Gong Y M and Si Y L 2002 Classification and evolution of metazoan traces at a topological level; Lethaia 35 $263-274$

Goyal S 2005 Sedimentology of the Talchir carbonates, Giridih Gondwana basin, Jharkhand; M.Sc. dissert., Allahabad University, 39 p.

Guha P K S, Mukhopadhyay S K and Das R N 1994 Trace fossils as indicator of paleoenvironment of Talchir Formation in the Ranigunj and Deogarh Group of Coalfields, India; Ninth Int. Gond. Symp., Abstract, Hyderabad, $55-56$.

Jamieson E R 1969 Paleoecology of Devonian reefs in western Canada; Proc. North Amer. Paleon. Conv. $1300-1340$.

Lindholm R 1987 A practical approach to sedimentology; (London: Allen and Unwin) $276 \mathrm{p}$.

Meadows P S, Reichelt A C, Meadows A and Waterworth J S 1994 Microbial and meiofaunal abundance, redox potential, $\mathrm{pH}$ and shear strength profiles in deep-sea Pacific sediments; J. Geol. Soc. London 151 $377-390$.

Milliman J D 1974 Marine carbonates (New York: Springer) $375 \mathrm{p}$.

Mohanty M and Das S 1997 Microbial signatures in lacustrine and fluvial carbonates; In: Gondwana (Permian) and Holocene examples India, Facies 36 234-238.

Monty C L and Mas J R 1981 Phanerozoic Stromatolites (ed.) Monty Claude, Springer-Verlag, 85-120.

Niyogi D 1961 Pattern of Talchir sedimentation in Burhai Gondwana basin, Bihar, India; J. Sedim. Petrol. 31 63-71.

Pal A K, Sen M, Ghosh R N and Das S N 1994 Marine incursions during Gondwana sedimentation in Damodar valley basins, Eastern India; Ninth Int. Gond. Symp., Abstract, Hyderabad, 63.

Pettijohn F J 1975 Sedimentary Rocks; Harper, New York, N.Y., Third edition, $628 \mathrm{p}$.

Pike J, Bernhard J M, Moreton S G and Butler I B 2001 Microbioirrigation of marine sediments in dysoxic environments: Implications for early sediment fabric formation and diagenetic processes; Geology 29 923-926. 
Platt H M 1989 Meiofauna: recent advances and economic assesment. Zoolog; J. Linnean Soc. 96 213-216.

Raisewell R 1971 The growth of Cambrian and Liassic concretions; Sedimentology 17 141-171.

Rao C N 1957 Trends of sedimentation in Giridih basin, Bihar, India; J. Sedim. Petrol. 27 435-446.

Reed F R C 1928 A Permo-Carboniferous marine fauna from Umaria Coalfield; Rec. Geol. Surv. India 60 469-476.

Rhoads D C 1975 The paleoecological and environmental significance of trace fossils; In: The study of trace fossils (ed.) Frey R W (New York: Springer) pp. 147-160.

Riemann F 1979 Nematoden aus den Brackwasser des Weser-Astuars und Beschreibung von Monhysteroidea; Cited by Funch, P. 2002 Marine meiofauna. Feltkursus I videregaende zoologi pa molslaboratoriet, 1-19.

Selles-Martinez J 1996 Concretion morphology, classification and genesis; Earth Sci. Rev. 41 177-210.

Seilacher A 1967 Bathymetry of trace fossils; Mar. Geol. 5 413-428.

Seilacher A 1978 Use of trace fossils for recognizing depositional environments; In: Trace fossil concepts, (ed.) Basin P B, pp. 175-201. Short Course No. 5; Soc. Econ. Pal. And Min., Tulsa, Oklahoma.
Sen D P 1991 Sedimentation patterns of the Talchir Group in the Giridih Gondwana basin, India: A case of multiple glacia 1 advance and retreat; Paleogeog. Paleoclim. Paleoeco. 86 339-352.

Sen D P and Banerjee T 1991 Permo-Carboniferous proglacial-lake sedimentation in the Sahajuri Gondwana basin, India; Sedim. Geol. 71 47-58.

Sengupta S, Bose D, Siva Prasad K and Das S S 1988 Karharbari and Barakar sedimentation in the Giridih basin, India; J. Geol. 60 35-57.

Sengupta S 2007 Introduction to sedimentology; Second edition, (New Delhi, India: CBS Publishers \& Distributor) $339 \mathrm{p}$.

Sengupta S, Chakraborty A and Bhattacharya H 1999 Fossil Polyplacophora (Mollusca) from upper Talchir sediments of Dudhi Nala, Hazaribagh, Bihar; J. Geol. Soc. India 54 523-527.

Thomsen E and Vorren T O 1984 Pyritization of tubes and burrows from Late Pleistocene continental shelf sediments off North Norway; Sedimentology 31 481-492.

Wignall P B 1991 Dysaerobic trace fossils and ichnofabrics in the Upper Jurassic Kimmeridge Clay of southern England; Palaios 6 264-270. 